\title{
Microencapsulation of Kabocha Pumpkin Carotenoids
}

\author{
Naomi M. Mulyadi, Tri D. Widyaningsih, Novita Wijayanti, Renny Indrawati, Heriyanto, and \\ Leenawaty Limantara
}

\begin{abstract}
Kabocha pumpkin (Curcubita maxima [Duchesne ex Lamb.]) is a potential source of carotenoids. However, the usage of carotenoids is limited due to their instability and also their susceptible degradation against harmful conditions such as base and acidic conditions, oxidation, and illumination. In this study, kabocha carotenoids were incorporated into microencapsulation containing chitosan, sodium alginate and sodium tripolyphosphate. The objective of this study is to determine the formulation of coating agents, carotenoid stability in acidic conditions for mimicking the microencapsulation process, and to characterize the microencapsulated carotenoids including the determination of the efficiency of carotenoid incorporation into microencapsulates. A mixture of sodium alginate, chitosan and sodium tripolyphosphate $(0.19 \mathrm{~g}: 1.92 \mathrm{~g}$ : $0.24 \mathrm{~g}, \mathrm{w} / \mathrm{w} / \mathrm{w}$ ) was the best of coating agents according to the physical characteristics and also its moisture content. Microcapsules obtained with and without addition of carotenoids were determined to be a microparticle size by SEM analysis. The products of microencapsulated carotenoids have the water content of around $5.4 \%$ to $7.1 \%$.The highest efficiency of microencapsulation obtained was $91 \%$ at the carotenoid concentration of $117.98 \mu \mathrm{g} \cdot \mathrm{g}^{-1}(0.5 \%$, w/v), although the efficiency was decreased with increasing carotenoids added to the microcapsules probably due to over loading of carotenoids used. The pattern of this efficiency was in line with $L^{*}$ and ${ }^{\circ}$ hue values, whereas not only $a^{*}$, $b^{*}$, and chroma values, but total carotenoids, and total provitamin $\mathrm{A}$ also increased.
\end{abstract}

Index Terms-Carotenoids, emulsion, kabocha (Curcubita maxima [Duchesne ex Lamb.]), microencapsulation, pumpkin.

\section{INTRODUCTION}

Carotenoids have several functional benefits for human body. Carotenoids have roles in epithelisation process, influencing cell progression of the fibroblast, antioxidant, in protecting agent of UV radiation and decreasing the skin cancer risk. In addition, some types of carotenoids have a role as provitamin A [1]. However carotenoids are susceptibly degraded by harmful conditions, i.e. light radiation, high

Manuscript received August 5, 2017; revised November 8, 2017. This project was supported by the Indonesian Ministry of Research, Technology, and Higher Education through the National Innovation System Research Grant (IRPI-2017), IbIKK Community Service Grant (No. 101/SP2H/PPM/DRPM/IV/2017), and National Strategic Excellent Research (PUSNAS) Grant (No. 120/SP2H/LT/DRPM/IV/2017). The authors wish to thank Prof. Yuzo Shioi (Shizuoka University, Japan) for his valuable comments and critical reading of the paper.

Naomi M. Mulyadi, Tri D. Widyaningsih, and Novita Wijayanti are with the Department of Agricultural Product Technology, Brawijaya University, Malang, Indonesia.

Renny Indrawati and Heriyanto are with Ma Chung Research Center for Photosynthetic Pigments (MRCPP) and Chemistry Study Program, Universitas Ma Chung, Malang, Indonesia.

Leenawaty Limantara is with Ma Chung Research Center for Photosynthetic Pigments (MRCPP), Universitas Ma Chung, Malang, Indonesia and Center for Urban Studies, Universitas Pembangunan Jaya, Jakarta, Indonesia (email: leenawaty.limantara@upj.ac.id). temperature, and the presence of acid or oxygen. These conditions may degrade their quality on disappearance of color, rancidity and decrease in bioactivity and food functional roles [2].

Some protecting techniques have been explored to protect pigments from the degradation. Encapsulation is a common way that protects bioactive molecules by entrapping them into other substances and also that changes the size of particles into nano- or microparticles. Microencapsulation is encapsulation which produces micro particles $(1 \mu \mathrm{m}$ to $1000 \mu \mathrm{m})$ [3]. Microencapsulation has been applied in some kind of food products and usually uses spray-drying (high temperature) as a drying method while microencapsulation conducted by freeze dryer is still rare. The Freeze drying method produces the best quality for final product and does not change the bioactive composition in food because it uses low temperature. Suitable coating agents are needed in the encapsulation process, because the coating agents give protecting barrier to the bioactive compounds. Chitosan and sodium alginate are two kinds of coating agents that have been used for microencapsulation in pharmacy. These two agents give a good synergy in forming transparent, flexible, and strong film, and have high tensile strength [4], [5]. Preparation of microcapsule via emulsification with biopolymer combined with freeze drying technology is known to produce microspheres, having a particle size ranging between $20 \mu \mathrm{m}$ and $5000 \mu \mathrm{m}$ [5].

Kabocha pumpkin (Cucurbita maxima) Duchesne is a potential carotenoids source. Kabocha has higher carotenoids content (285.91 mg·100 $\mathrm{g}^{-1}$ ) than local pumpkins (26.62 $\mathrm{mg} \cdot 100 \mathrm{~g}^{-1}$ ) [6]. In present study, the microencapsulation process of carotenoids from kabocha was conducted by freeze dryer. The best proportion of chitosan-sodium alginate-sodium tripolyphosphate (STPP) as coating agents of microencapsulated carotenoids would be chosen. The addition of different carotenoid concentrations was evaluated to determine microcapsules characteristics, such as color properties and encapsulation efficiency. The final product of microencapsulated kabocha carotenoids can be utilized as natural carotenoid powder with high stability.

\section{MATERIALS AND METHODS}

\section{A. Materials and Reagents}

Kabocha and sunflower oil (Golden Bridge, Malaysia) were purchased from Lai-Lai Fruit Market (Malang, Indonesia). Chitosan and Sodium Tripolyphosphate (STPP) (Changzhou Kamadi Trading Co., Ltd, Changzhou, China), sodium alginate (Qingdao Hyzlin Biology Development, China), tween 80 (Sigma Aldrich, St. Louis, United States), demineralized water with resistivity $100 \times 104 \Omega \mathrm{cm}, \mathrm{N} 2$ gas (UHP grade, PT Samator, Surabaya, Indonesia) were used directly. Glacial 
acetic acid, acetone, $n$-hexane are an analytical grade from Merck (Darmstadt, Germany).

\section{B. Sample Preparation}

The fruit of Kabocha pumpkin was separated from the peel and then cut into small pieces. The pumpkin fruit was dried by a vacuum oven (VO-200, Memmert, Schwabach, Germany) at $50{ }^{\circ} \mathrm{C}$ and 2 mbar for $24 \mathrm{~h}$. The dried fruit was ground using a grinder (M20, IKA-Werke, Selangor, Malaysia). The pumpkin powders were kept inside a desiccator in dark condition for future analysis.

\section{Carotenoids Extraction, Formulation of Coating Agents, and Stability Test in Emulsion System}

Carotenoids were extracted from $20 \mathrm{~g}$ of dried kabocha powders with $30 \mathrm{~mL}$ of n-hexane by stirring for $40 \mathrm{~min}$ and then filtered through a filter paper. The extraction was repeated 2 times under a red light. The carotenoid extracts were dried by evaporation (Eyela SB-1100 rotary evaporator, Tokyo Rikakikai Co. LTD, Japan) and continued by the stream of nitrogen gas. The dried carotenoid extracts were kept at $-30{ }^{\circ} \mathrm{C}$.

Microencapsulation agents were comprised of sodium alginate, chitosan and STPP mixture (ACT) in 5 formulations (Table I). The microparticles with the ACT1 formulation were prepared by adding $96 \mathrm{~mL}$ of chitosan (2\%, w/v) into $19.2 \mathrm{~mL}$ of sodium alginate solution ( $1 \%, \mathrm{w} / \mathrm{v})$ and followed by addition of $4.8 \mathrm{~mL}$ of STPP solution $(0.5 \%$, w/v) and $0.96 \mathrm{~mL}$ of acetic acid. This mixture was homogenized three times by a UltraTurax Homogenizer T-18 (IKA) at $15000 \mathrm{rpm}$ for $5 \mathrm{~min}$ $(1 \mathrm{rpm}=1 / 60 \mathrm{~Hz})$. After storage at $-15{ }^{\circ} \mathrm{C}$ for $24 \mathrm{~h}$, the mixture was then lyophilized at $-47^{\circ} \mathrm{C}$ for $24 \mathrm{~h}$ by a freeze dryer (Labconco, Kansas City, USA). Other formulations of coating agents were prepared with the same manner as described above.

TABLE I: Formulations OF COATING AgENTS IN 120 G OF DEMINERALIZED WATER

\begin{tabular}{|c|c|c|c|c|c|c|c|}
\hline \multirow[t]{2}{*}{ Formula } & \multicolumn{2}{|c|}{$\begin{array}{c}\text { Sodium } \\
\text { alginate (1) }\end{array}$} & \multicolumn{2}{|c|}{$\begin{array}{c}\text { Chitosan } \\
\text { (2) }\end{array}$} & \multicolumn{2}{|c|}{$\begin{array}{l}\text { STPP } \\
(3)\end{array}$} & \multirow{2}{*}{$\begin{array}{c}\text { Mass Ratio of } \\
1: 2: 3 \\
(\mathrm{w} / \mathrm{w} / \mathrm{w})\end{array}$} \\
\hline & $\%$ & $\mathrm{~V}$ & $\%$ & $\mathrm{~V}$ & $\%$ & $\mathrm{~V}$ & \\
\hline ACT1 & 1.0 & 19.2 & 2.0 & 96.0 & 5.0 & 4.8 & 0.19:1.92:0.24 \\
\hline АCT2 & 2.0 & 37.5 & 4.0 & 75.0 & 2.0 & 7.5 & 0.75:3.00:0.15 \\
\hline АСТЗ & 5.0 & 40.0 & 5.0 & 80.0 & 0.0 & 0.0 & 2.00:4.00:0.00 \\
\hline ACT4 & 2.0 & 40.0 & 2.0 & 80.0 & 0.0 & 0.0 & 0.80:1.60:0.00 \\
\hline ACT5 & 1.0 & 60.0 & 1.0 & 60.0 & 0.0 & 0.0 & 0.60:0.60:0.00 \\
\hline
\end{tabular}

Approximately $0.02 \mathrm{~g}$ of the dried carotenoid was dissolved in $0.2 \mathrm{~mL}$ of acetone and then titrated with $9.8 \mathrm{~mL}$ of acetic acid solution in different $\mathrm{pH}(\mathrm{pH} 3$ and $\mathrm{pH} 4)$ containing a Tween 80 solution $(0.1 \%$, w/v). The stability of the carotenoids was observed by recording the absorption spectrum in this emulsion at $0 \mathrm{~min}, 45 \mathrm{~min}, 100 \mathrm{~min}$, and $150 \mathrm{~min}$ using 1700 UV-Vis Spectrophotometer (Shimadzu, Kyoto, Japan). The dried carotenoids in $10 \mathrm{~mL}$ of acetone were used as the control sample.

\section{Microencapsulation of Carotenoids}

Preparation of carotenoids in emulsion system was adapted from the method of [7], while the microencapsulation of carotenoids was performed according to the method published elsewhere [8] with the slight modifications. Initially, the dried carotenoids in the different masses were dissolved in trace amount of acetone $(0.5 \mathrm{~mL})$ and sunflower oil $(1.5 \mathrm{~mL})$ (the range of carotenoid concentration was $0.5-3.0 \%$, w/v) and then added with Tween 80 ( $0.5 \mathrm{~g})$ and sodium alginate (1\%) in $19.2 \mathrm{~mL}$ of demineralized water. This emulsion was then homogenized at $1500 \mathrm{rpm}$ for $5 \mathrm{~min}$. The carotenoid emulsion was mixed with chitosan (2\%) in $96 \mathrm{~mL}$ of demineralized water and homogenized at $15000 \mathrm{rpm}$ for 1 min. Afterward STPP (5\%, $4.8 \mathrm{~mL})$ and acetic acid (2 mL) were added to this solution. The homogenization was continued for $5 \mathrm{~min}$. To separate microencapsulated carotenoids from acidified water, the homogenized solution was centrifuged (Kubota, Tokyo, Japan) at $11500 \mathrm{rpm}$ and at $4^{\circ} \mathrm{C}$ for $20 \mathrm{~min}$. The pellet of microencapsulated carotenoids was collected and stored at $-15{ }^{\circ} \mathrm{C}$ for $24 \mathrm{~h}$. The lyophilized process of microencapsulated carotenoids was performed by using a Freeze dryer (Labconco) at $-47^{\circ} \mathrm{C}$ for $24 \mathrm{~h}$. The freeze-dried product was crushed in a mortar and sieved by a standard sieve (80 mesh).

\section{E. Characterization of Microcapsules}

Microcapsules (0.001 g) were extracted with a mixture of acetone and water solution $(8: 2, \mathrm{v} / \mathrm{v})$ and then centrifuged at $10000 \mathrm{rpm}$ for $15 \mathrm{~min}$. The supernatant was then partitioned with n-hexane and the hexane layer was dried under the stream of nitrogen. The dried carotenoid extract was then re-dissolved in n-hexane and an absorption spectrum was recorded in the range of $250-600 \mathrm{~nm}$. The efficiency of microencapsulation was then calculated based on the ratio of the absorption at the position of absorption maximum between the microencapsulated carotenoids and initially added carotenoids.

The $L^{*}, a^{*}$, and $b^{*}$ values of the microcapsules were recorded by a Colorflex EZ (Hunter Associates Laboratory, Inc., Reston, USA). The hue and chroma values were also calculated. Total carotenoids and pro-vitamin A were estimated based on Gross formula [9] and NAS-NRC [10], respectively.

\section{F. Data Analysis}

A SPSS 21 program with One-Way ANOVA (95\%) and Duncan's Multiple Range Test was used for the statistical analysis.

\section{RESUlTS AND DisCUSSION}

\section{A. Determination of the Best Formula for Coating Agents}

The composition of the coating agents is important for the final product. A high amount of sodium alginate produces a spongy structure due to the property of sodium alginate as a gel. Alginate contains gulunorat $(G)$ and manuronat chains which the $G$ chain will affect in the formation of gel [11]. The physical characteristics of formulations without the addition of STPP (ACT3, ACT4, and ACT5) revealed the sponge structure and formation of aggregates in the powders (Figure not shown). In addition, the moisture contents of these powders were higher than $10 \%$. On the other hand, formulations with STPP (ACT1 and ACT2) produced dry and soft powders with lower moisture contents (less than 8\%). However, the powders from the formulation of ACT2 were formed some aggregates with a sponge-like structure. Among 5 formulations tested, therefore, the best formulation of 
coating agents was ACT1 in the following composition: sodium alginate: chitosan: STPP: demineralized water $=0.19$ $\mathrm{g}: 1.94 \mathrm{~g}: 0.20 \mathrm{~g}: 120 \mathrm{~g}$. Besides the formulation, the process of microencapsulation is determined by the speed and duration of homogenization process, and other continuous procedures, i.e. centrifugation. Addition of ionic agent, such as STPP, can create cross interaction and improve the characteristic of the powder. STPP also facilitates chitosan to build crosslink with itself and addition of sodium alginate acts as a filler to strengthen the structure [8].

\section{B. Stability Test of Carotenoids}

The solution used for the microencapsulation was found to have low $\mathrm{pH}$ with a range of $\mathrm{pH} 3.6$ to $\mathrm{pH} 4.0$, therefore, a stability test on carotenoids was needed to ensure the formulation. The stability of kabocha carotenoids in the emulsion system with different $\mathrm{pH}$ was evaluated from their absorption spectra (Fig. 1). The absorption of carotenoids in acetone as a control (Fig. 1 a) showed a slight increase in the intensity due to evaporation of acetone during measurements.

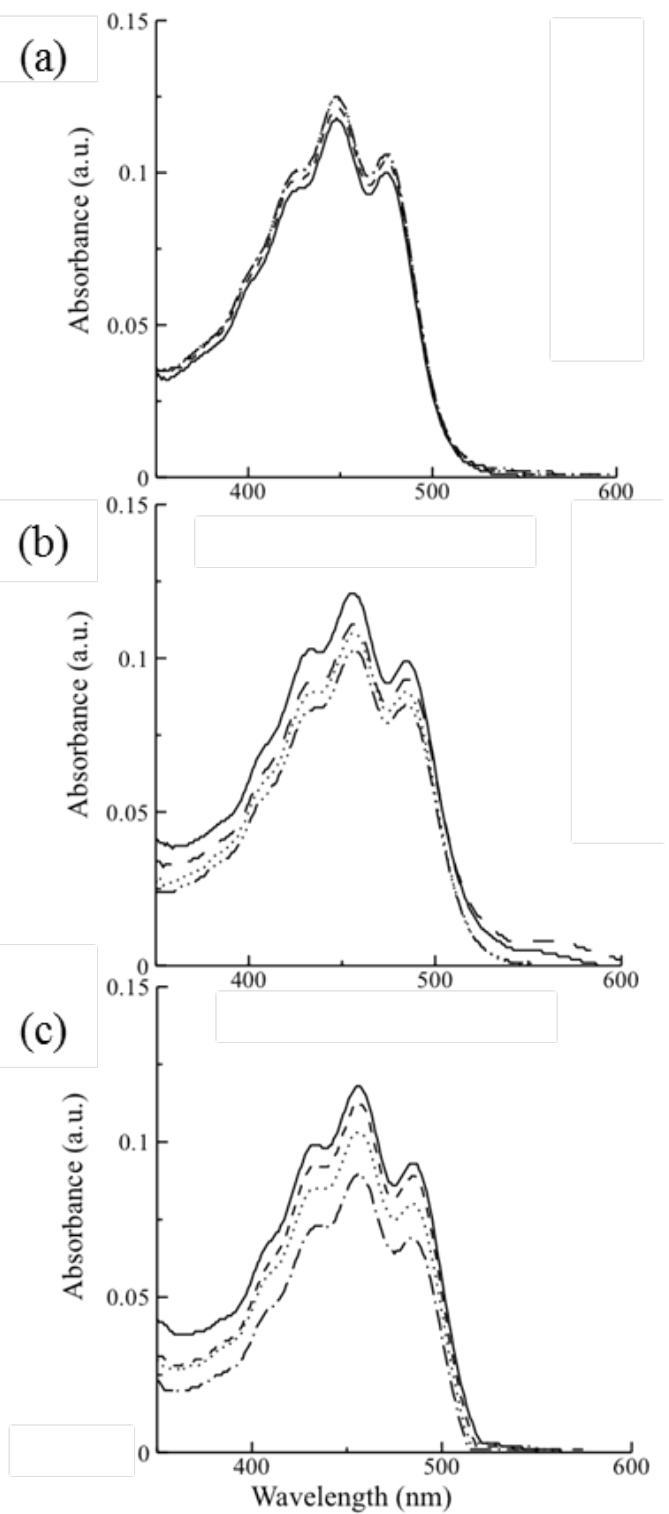

Fig. 1. Absorption spectra of kabocha carotenoids in acetone (a), emulsion systems at $\mathrm{pH} 4$ (b) and $\mathrm{pH} 3$ (c) incubated at room temperature for $0 \mathrm{~min}$ $(--), 45 \min (--), 100 \mathrm{~min}(\ldots \ldots)$ and $150 \mathrm{~min}\left(-.^{-} .-\right)$.

In the emulsion with a low $\mathrm{pH}$, it was shown that the carotenoid spectra decreased in the intensity. After 150 min the absorbance of carotenoids has decreased to $18.8 \%$ and $15.2 \%$ in the emulsion with $\mathrm{pH}$ of 3 and 4 , respectively. Based on the stability test, the maximum processing time for microencapsulation of carotenoids was set to be 60 min which least affects the carotenoid stability of $7.8 \%$ for both $\mathrm{pH}$.

In Fig. 1, the spectra of carotenoids dissolved in acetone solution have 3 bands with absorption maxima at $424 \mathrm{~nm}, 448$ $\mathrm{nm}$, and $474 \mathrm{~nm}$. In the emulsion system, the bands were red-shifted to about $6 \mathrm{~nm}$ to $8 \mathrm{~nm}$. This shift is due to the aggregation process of carotenoids with their environment and it is usually called as a J-aggregation. Previously it was reported that a bathochromic shift of carotenoids occurred because of the interaction of carotenoids with the surfactants that produces an aggregate [12]. In the case of fucoxanthin, the presence of water caused the aggregation of fucoxanthin in acetone solution which shows the bathochromic shift up to $7 \mathrm{~nm}$ [13]. It was suggested that the presence of water in carotenoid solution might cause aggregation of carotenoids because there is a strong hydrophobic tensile strength [14].

\section{Characterization of Microencapsulated Carotenoids}

The microencapsulated carotenoid powders have low moisture contents in the range of $5.41 \%$ to $7.08 \%$. The moisture contents of the microencapsulated kabocha carotenoids were in line with the results reported before [15]. Moisture contents of microencapsulated powders dried by different methods of spray-freeze drying, freeze-drying, and spray-drying were $4.15 \%$ to $6.63 \%, 6.7 \%$ to $6.99 \%$ and $3.56 \%$ to $6.40 \%$, respectively [15].

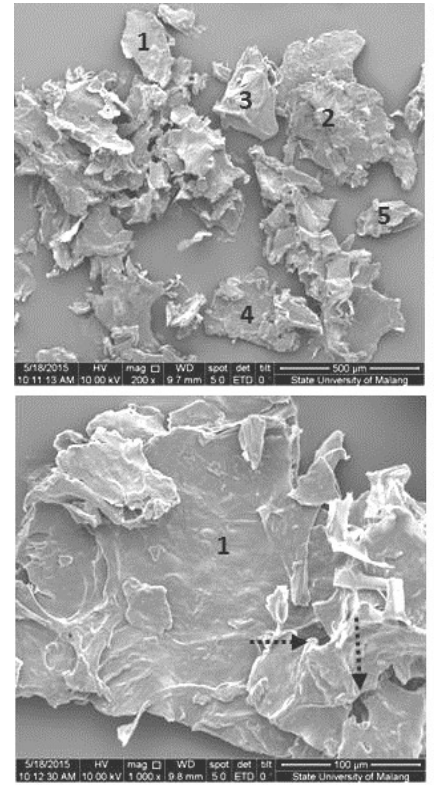

(a)

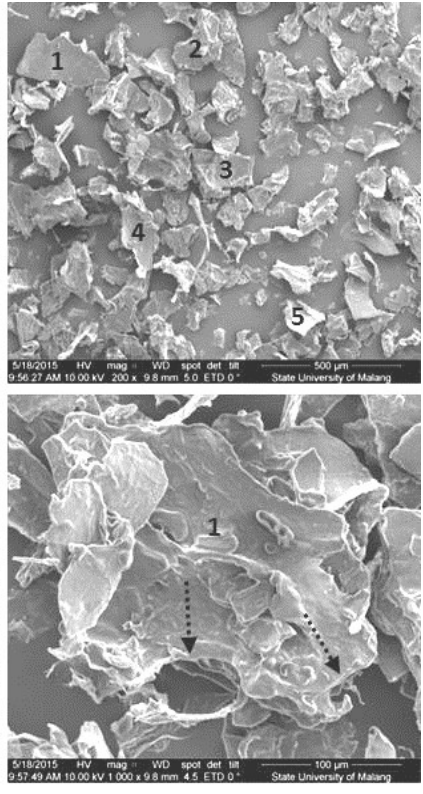

(b)
Fig. 2. SEM images of the empty microcapsules of ACT1 formulation (a) and the carotenoid-filled microcapsules with the addition of 3\% carotenoids (b) observed at magnifications of 200 times (above) and 1000 times (below). Five specimens indicated with the numbers were used for calculating the average of diameter of microcapsules and the arrow indicates a porous structure of microcapsules.

SEM images of microcapsules depict the morphological characteristics of microparticles. The microencapsulated carotenoid powders have smaller diameter than that of empty one (Fig. 2, 200 times magnification). The large diameter of the empty microcapsules might be affected by the overlapped 
powders during the SEM analysis and also the microcapsules have not been sieved. The average diameters of the empty and carotenoid-filled microcapsules were $337.88 \mu \mathrm{m}$ and 214.26 $\mu \mathrm{m}$, respectively, indicating that microencapsulation process has produced the micro-scale particles. Reference [5] revealed that microencapsulation by a freeze drying method produces a varied particle size of around $20-5000 \mu \mathrm{m}$.

At the magnification of 1000 times (Fig. 2, below), carotenoid-filled microcapsules appeared a rougher surface than the empty microcapsules. It is suggested that the pigment has been entrapped to the coating agents. Other characteristics of microcapsules were irregular shape with porous and slab features and a variation in particle size probably due to the sample preparation during freeze drying and crushing steps. These SEM results were in agreement with other study by [16] The morphology of freeze dried microcapsules was irregular shape having a slab-like structure. These morphological features came from the freeze dried matrix subjected to crush by mortar.

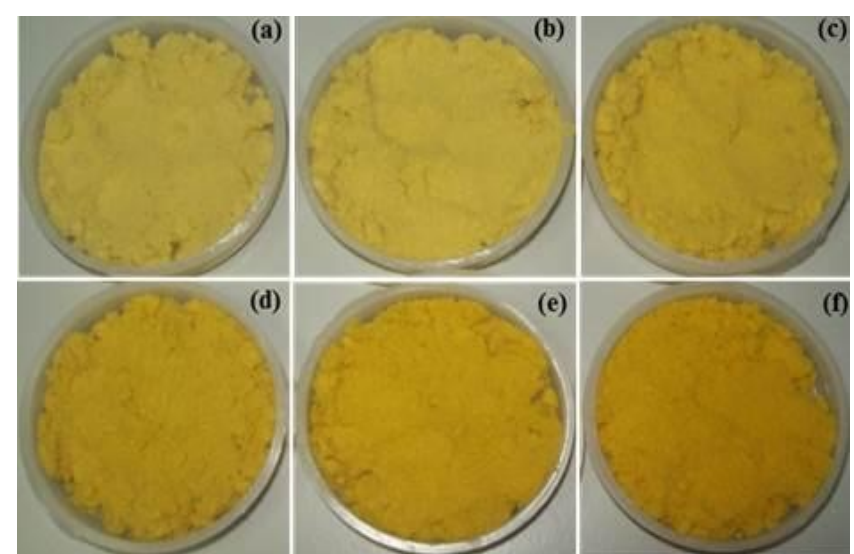

Fig. 3. Microencapsulated carotenoids powder with the ACT1 formulation using different addition of carotenoid concentrations, i.e. $0.5 \%$ (a), $1.0 \%$ (b), $1.5 \%$ (c), $2.0 \%$ (d), $2.5 \%$ (e) and $3.0 \%$ (f).

Color of the microencapsulated carotenoid powders was visually seen in the range from yellow to orange (Fig. 3). The addition of carotenoids significantly affected to the color change of the microencapsulated carotenoid powders. Table II summarizes color values, i.e. $L^{*}, a^{*}, b^{*}, C^{*}$ and ${ }^{\circ}$ hue, from the samples. The positive correlations of $a^{*}, b^{*}$ and $C^{*}$ with the amount of added carotenoids were seen because of increment of carotenoid concentration, while $\mathrm{L}^{*}$ and ${ }^{\circ}$ hue gave a negative correlation. The results of color measurement were in agreement with the literatures [17], [18]. A study has reported that $L^{*}$ value had a negative correlation to the addition of pigment, because higher pigment content will increase the darkness of sample as a consequence on decrease in $L^{*}$ value. An $L^{*}$ value had a strong correlation with the total carotenoids, whereas $b^{*}$ and chroma values had a moderate correlation with total carotenoids and had a strong correlation with the increase in lutein. The degree of hue value had a negative correlation with total carotenoids [17]. Other report showed that $a^{*}, b^{*}$, and $C^{*}$ values also have a positive correlation with $\beta$-carotene content and total carotenoids [18].

Total carotenoids and pro-vitamin A of microencapsulated carotenoids powder increased with the increase in the carotenoid concentrations (Table III). Reference [9] reported the daily need for vitamin A in a man is $1000 \mathrm{RE} 8$. It means that by consuming about $100 \mathrm{~g}$ of microencapsulated carotenoids (the addition $2.5 \%$ and $3.0 \%$ carotenoids), it may fulfil the daily need for vitamin A. Based on SNI 7709-2012, maximum fortification of vitamin A to the vegetable oil is 45 $\mathrm{IU} \cdot \mathrm{g}^{-1}$. The addition of $1.05 \mathrm{~g}$ to $4.20 \mathrm{~g}$ of the microencapsulated carotenoids to $1 \mathrm{~g}$ of vegetable oil is enough to achieve the standardization of food fortification. The increase in carotenoid concentration added in microencapsulation process caused the decrease in efficiency. Table III summarizes the percentage of encapsulation efficiency with the addition of several portions of carotenoids. This result showed the same trend with other reports. Reference [19] concluded that the loading carotenoids with high concentration did not provide better encapsulation efficiency. This phenomenon was also observed in other polymeric matrices that over loading of encapsulated materials caused some decrease in the encapsulation efficiency [20].

TABLE II: CHROMATIC VALUES OF THE MICROENCAPSULATED CAROTENOIDS FROM KABOCHA POWDERS WITH ACT1 FORMULATION

\begin{tabular}{cccccc}
\hline \hline $\begin{array}{c}\text { Carotenoids } \\
(\mathrm{w} / \mathrm{v})\end{array}$ & $L^{*}$ & $a^{*}$ & $b^{*}$ & ${ }^{0}$ Hue & $C^{*}$ \\
\hline & & & & & \\
\hline & 76.21 & 3.64 & 48.91 & 85.76 & 49.05 \\
1.5 & $\pm 2.14^{\mathrm{a}}$ & $\pm 0.62^{\mathrm{a}}$ & $\pm 2.26^{\mathrm{a}}$ & $\pm 0.62^{\mathrm{a}}$ & $\pm 2.28^{\mathrm{a}}$ \\
& 76.61 & 7.85 & 60.33 & 82.59 & 60.84 \\
& $\pm 0.46^{\mathrm{a}}$ & $\pm 0.92^{\mathrm{b}}$ & $\pm 3.57^{\mathrm{b}}$ & $\pm 0.78^{\mathrm{b}}$ & $\pm 3.60^{\mathrm{b}}$ \\
1.5 & 74.74 & 9.25 & 65.74 & 81.97 & 66.39 \\
& $\pm 0.86^{\mathrm{ab}}$ & $\pm 0.35^{\mathrm{C}}$ & $\pm 3.39^{\mathrm{c}}$ & $\pm 0.66^{\mathrm{b}}$ & $\pm 3.31^{\mathrm{c}}$ \\
2.0 & 72.77 & $10.19 \pm$ & 69.99 & 81.70 & 70.73 \\
& $\pm 0.60^{\mathrm{b}}$ & $0.10^{\mathrm{c}}$ & $\pm 3.33^{\mathrm{d}}$ & $\pm 0.36^{\mathrm{bc}}$ & $\pm 3.30^{\mathrm{d}}$ \\
2.5 & 70.34 & $11.66 \pm$ & 72.34 & 80.85 & 73.28 \\
& $\pm 2.57^{\mathrm{C}}$ & $0.43^{\mathrm{d}}$ & $\pm 1.14^{\mathrm{e}}$ & $\pm 0.23^{\mathrm{c}}$ & $\pm 1.18^{\mathrm{de}}$ \\
3.0 & 70.34 & $14.02 \pm$ & 74.69 & 79.37 & 76.00 \\
& $\pm 1.21^{\mathrm{c}}$ & $1.17^{\mathrm{e}}$ & $\pm 1.20^{\mathrm{f}}$ & $\pm 0.87^{\mathrm{d}}$ & $\pm 1.21^{\mathrm{e}}$ \\
$\mathrm{Y}$ & $-1.49 \mathrm{x}+$ & $1.84 \mathrm{x}+$ & $4.83 \mathrm{x}+$ & $-1.07 \mathrm{x}+$ & $5.04 \mathrm{x}+$ \\
$\mathrm{R}^{2}$ & 78.72 & 3.00 & 48.42 & 85.78 & 48.41 \\
& 0.96 & 0.94 & 0.90 & 0.88 & 0.91 \\
\hline
\end{tabular}

*Means \pm SD. The difference notation shows that the data are significantly different at $p \geq 0.05$.

TABLE III: TOTAL CAROTENOIDS, PROVIT AMIN A, AND MiCROENCAPSULATION EFFICIENCY OF THE MiCROENCAPSULATED CAROTENOIDS FROM KABOCHA POWDERS WITH THE ACT1 FORMULATION

\begin{tabular}{|c|c|c|c|c|}
\hline \multirow[b]{2}{*}{$\begin{array}{c}\% \\
\text { Carotenoids } \\
\text { (w/v) }\end{array}$} & \multirow{2}{*}{$\begin{array}{c}\text { Total } \\
\text { Carotenoids } \\
\left(\mu \mathrm{g} \cdot \mathrm{g}^{-1}\right. \\
\mathrm{dw})^{*}\end{array}$} & \multicolumn{2}{|c|}{ Total Provitamin A } & \multirow[b]{2}{*}{$\begin{array}{c}\% \\
\text { Efficiency* }\end{array}$} \\
\hline & & $\begin{array}{l}\mathrm{RE} / \\
100 \mathrm{~g} \\
\mathrm{dw}^{*}\end{array}$ & $\begin{array}{c}\mathrm{IU} / \\
100 \mathrm{~g} \\
\mathrm{dw}^{*}\end{array}$ & \\
\hline \multirow{2}{*}{0.5} & 117.98 & 321.90 & 1073.00 & 90.86 \\
\hline & $\pm 10.41^{\mathrm{a}}$ & $\pm 28.39^{a}$ & $\pm 94.64^{\mathrm{a}}$ & $\pm 6.17^{\mathrm{a}}$ \\
\hline \multirow{2}{*}{1.0} & 150.00 & 474.14 & 1580.47 & 83.37 \\
\hline & $\pm 11.70^{b}$ & $\pm 36.99^{b}$ & $\pm 123.28^{b}$ & $\pm 7.82^{\mathrm{ab}}$ \\
\hline \multirow{2}{*}{1.5} & 207.38 & 691.03 & 2303.42 & 78.20 \\
\hline & $\pm 18.00^{\mathrm{C}}$ & $\pm 59.97^{C}$ & $\pm 199.92^{\mathrm{C}}$ & $\pm 2.93^{b}$ \\
\hline \multirow{2}{*}{2.0} & 235.51 & 822.68 & 2742.26 & 62.51 \\
\hline & $\pm 24.06^{\mathrm{d}}$ & $\pm 84.03^{\mathrm{d}}$ & $\pm 280.10^{d}$ & $\pm 4.68^{\mathrm{C}}$ \\
\hline \multirow{2}{*}{2.5} & 279.17 & 1045.88 & 3486.27 & 58.55 \\
\hline & $\pm 13.47^{\mathrm{e}}$ & $\pm 50.47^{\mathrm{e}}$ & $\pm 168.23^{\mathrm{e}}$ & $\pm 5.68^{\mathrm{C}}$ \\
\hline \multirow{2}{*}{3.0} & 318.29 & 1287.00 & 4290.01 & 54.72 \\
\hline & $\pm 24.64^{f}$ & $\pm 99.64^{f}$ & $\pm 332.15^{\mathrm{f}}$ & $\pm 3.36^{\mathrm{C}}$ \\
\hline \multirow{2}{*}{0.5} & 117.98 & 321.90 & 1073.00 & 90.86 \\
\hline & $\pm 10.41^{a}$ & $\pm 28.39^{a}$ & $\pm 94.64^{\mathrm{a}}$ & $\pm 6.17^{a}$ \\
\hline \multirow{2}{*}{1.0} & 150.00 & 474.14 & 1580.47 & 83.37 \\
\hline & $\pm 11.70^{\mathrm{b}}$ & $\pm 36.99^{b}$ & $\pm 123.28^{b}$ & $\pm 7.82^{\mathrm{ab}}$ \\
\hline
\end{tabular}

*Means \pm SD. The difference notation shows that the data are significantly different at $p \geq 0.05$.

The centrifugation process also caused the decreasing in 
microencapsulation efficiency. It was estimated that some pigments having high polarity were soluble in aqueous solution and dissolved into the supernatant. HPLC analysis was performed on microencapsulated carotenoid powders and the supernatant after centrifugation [21]. The results showed that the polar carotenoids, i.e., antheraxanthin, lutein, and zeaxanthin were present in higher amount in the supernatant than non-polar carotenoids such as $\alpha$ - and $\beta$-carotene (1.1 to 1.9 times), while in the microencapsulated carotenoid powders, the relative concentration of non-polar carotenoids was 1.5 to 4.4 times higher than that of polar carotenoids. This result proved the loss of polar carotenoids in the supernatant during the centrifugation process. Centrifugation process is commonly used to separate bioactive compounds which have been entrapped into coating agents from unentrapped one [8].

\section{CONCLUSION}

Kabocha carotenoids can be entrapped with $2 \%$ chitosan, 1\% sodium alginate and 5\% STPP (1.92 g : $0.19 \mathrm{~g}: 0.24 \mathrm{~g}$, $\mathrm{w} / \mathrm{w} / \mathrm{w})$ to have a better microencapsulated products. The empty and carotenoid-filled microcapsules have an irregular shape, stable and porous structures, microsphere size with the average diameters between $214.26 \mu \mathrm{m}$ and $337.88 \mu \mathrm{m}$. The concentration of carotenoids added to the microencapsulation influences the micro encapsulation efficiency, color values, total carotenoids and also provitamin A.

\section{REFERENCES}

[1] A. C. Pintea, B. S. Andrei, and C. Socaciu, "HPLC analysis of carotenoids in four varieties of Calendula Officinalis L. flowers," Acta Biologica Szegendiensis, vol. 47, pp. 37-40, September 2003.

[2] C. S. Boon, D. J. McClements, J. Weiss, and E. A. Decker, "Factors influencing the chemical stability of carotenoids in foods," Critical Reviews in Food Science and Nutrition, vol. 50, pp. 515-532, June 2010.

[3] M. N. Singh, K. S. Y. Hemant, M. Ram, and H. G. Shivakumar, "Microencapsulation: A promising technique for controlled drug delivery,” Research in Pharmaceutical Sciences, vol. 5, pp. 65-77, July 2010.

[4] E. Rudnik, Compostable Polymer Material, Netherland: Elsevier, 2008.

[5] N. J. Zuidam and E. Shimoni, "Overview of microencapsulates for use in food products or processes and methods to make them," in Encapsulation Technologies for Active Food Ingredients and Food Processing, N. J. Zuidam, Nedović, V. A., ed. New York: Springer, 2010.

[6] S. R. Kim, T. Y. Ha, H. N. Song, Y. S. Kim, and Y. K. Park, "Comparison of nutritional composition and antioxidative activity for Kabocha squash and pumpkin,” Korean Journal of Food Science and Technology, vol. 4, pp. 171-172, 2005.

[7] W. Klaypradit and Y. W. Huang, "Chitosan-based encapsulation for tuna oil," Ph.D dissertation, The University of Georgia, Georgia, 2006.

[8] S. Purwatiningsih, L. Ambarsari, Y. A. Sari, and Y. Nugraha, "Ketoprofen encapsulation optimization with chitosan-alginate cross-linked with sodium tripolyphosphate and its release mechanism determination using in vitro dissolution," International Journal of Recent Research and Applied Studies, vol. 14, pp. 141-149, 2013.

[9] J. Gross, Pigments in Vegetable: Chlorophylls and Carotenoid, New York: Van Nostrand Reinhold, 1991.

[10] NAS-NCR, Recommended Dietary Allowances, 8th ed. Washington D.C.: Food and Nutrition Board, 1974.

[11] I. Donati, S. Holtan, Y. A. Mørch, M. Borgogna, M. Dentini, and G. Skjåk-Bræk, "New hypothesis on the role of alternating sequences in Calcium-alginate gels,” Biomacromolecules, vol. 6, pp. 1031-1040. January 2005.

[12] C. H. Lan, R. Fougere, and Y. Wache, "Increase in stability and change in supramolecular structure of $\beta$-karoten through encapsulation into polylactic acid nanoparticles," Food Chemistry, vol. 124, pp. 42-49, January 2011.

[13] Heriyanto and L. Limantara, "Photo-stability and thermo-stability studies of fucoxanthin isomerization," Proccedings of Natural Pigments Conference for South East Asia, ed. L. Limantara, Heriyanto, E. Sadtono, pp. 73-78, 2010.

[14] R. Giovannetti, L. Alibabaei, and F. Pucciarelli, "Kinetic model for astaxanthin aggregation in water-methanol mixtures," Spectrochimica Acta Part A, vol. 73, pp. 157-162, July 2009.

[15] S. Y. Hundre, P. Karthik, and C. Anandharamakrishnan, "Effect of whey protein isolate and $\beta$-cyclodextrin wall system on stability of microencapsulated vanillin by spray-freeze drying method," Food Chemistry, vol. 174, pp. 16-24, May 2015.

[16] S. Tandale, "Microencapsulation of vitamin C and garlic acid in whey protein concentrate by spray and freeze drying-Characterization and degradation kinetics,” M.S. thesis, The University of Georgia, Georgia, 2007.

[17] R. A. Itle and E. A. Kabelka, "Correlation between L*a*b* color space values and carotenoid content in pumpkins and squash (Cucurbita spp.),” Horticultural Science, vol. 44, pp. 633-637, June 2009.

[18] A. Seroczyńska, A. Korzeniewska, J. Sztangret-Wiśniewska, K. Niemirowicz-Szczytt, and M. Gajewski, "Relationship between carotenoids content and flower or fruit flesh colour of winter squash (Cucurbita maxima Duch.),” Folia Horticulturae, vol. 18, pp. 51-61. April 2006.

[19] P. Thamaket and P. Raviyan, "Preparation and physical properties of carotenoids encapsulated in chitosan cross-linked tripolyphosphate nanoparticles," Food and Applied Bioscience Journal, vol. 3, pp. 69-84, 2015.

[20] N. Liu and H. J. Park, "Chitosan coated nanoliposome as vitamin E carrier,” Journal of Microencapsulation, vol. 26, pp. 235-242, April 2009.

[21] N. M. Mulyadi, “Identifikasi, komposisi, kandungan dan mikroenkapsulasi karotenoid kabocha (Cucurbita maxima L.) menggunakan kitosan-sodium alginat-STPP [Identification, composition, content and microencapsulated carotenoids of kabocha (Cucurbita maxima L.) using chitosan-sodium alginate-STPP],” Undergraduate thesis, Universitas Brawijaya, Malang, 2015.

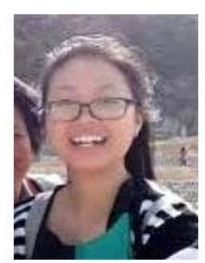

Naomi Megananda Mulyadi was born in Tulungagung, Indonesia, on 30 January 1993. She graduated with honor from Brawijaya University, Indonesia, in 2015, obtained bachelor degree in food technology. She was interested on biochemistry, food analysis, as well as new product development. She has started to be an entrepreneur in food manufacture.

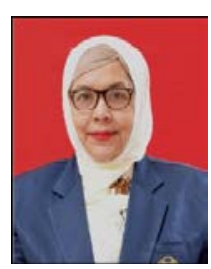

Tri Dewanti Widyaningsih was born in Yogyakarta, Indonesia, in 1961. She received bachelor degree in food processing from Gadjah Mada University, Yogyakarta, Indonesia, in 1985, master degree in community nutrition and doctoral degrees in functional food from Airlangga University, Surabaya, Indonesia in 1998 and 2011, respectively.

In 1998, she joined the Department of Agricultural Technology, Brawijaya University as a lecturer. Her current research interests include diet nutrition, functional food, bioactive compound, herbal supplement, food immunology, and food metabolism. She has been published a journal in Journal of Food and Nutrition Research, International Journal of PharmTech Research, Food and Agricultural Immunology, etc.

Dr. Widyaningsih was the head of food nutrition laboratories in the Department of Agricultural Technology, Brawijaya University, Indonesia. She was the recipient of Satyalancana Karya Satya awards, excellent lecturer awards, prospective innovation awards, and granted a patent (HAKI) for the grass jelly derivative product in the last ten years.

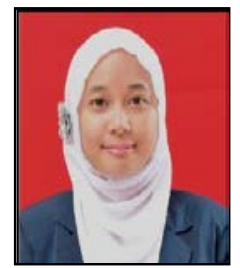

Novita Wijayanti was born in Jember, Indonesia, in 1980. She received bachelor and master degree in science and food technology from the Brawijaya University, Indonesia, in 2004 and 2013, respectively. Her major field of study is agricultural product technology and biotechnology of agroindustry.

In 2012, she joined the Department of Agricultural Technology, Brawijaya University as a lecturer. Her 
current research interests include product development, functional food, dietary supplements, food chemistry, food serving management, physiology and metabolism of nutrients. She has been published a journal in national and international level.

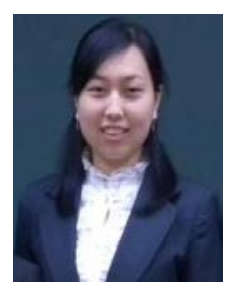

Renny Indrawati was born in Malang, East Java, Indonesia, on 29 May 1986. She received the undergraduate degree (bachelor in food technology) with a cum laude honor from Brawijaya University, Indonesia, in 2008. She began her career in research by joining Ma Chung Research Center for Photosynthetic Pigments (MRCPP) as a research assistant in 2009, and she is deeply interested in the development of functional food related to natural pigments. In 2011, she graduated with a summa cum laude honor from Satya Wacana Christian University, Indonesia, majored in Chlorophyll and Carotenoid. She subsequently finished the second master degree by research (master of international natural science) in 2012 at Kwansei Gakuin University, Japan.

Currently, she is a researcher at MRCPP as well as a lecturer assistant at Chemistry Study Program, Universitas Ma Chung, Indonesia. She has been involved in some prestigious national research grants, such as excellent research on national strategy, competitive research grant, and national innovation system research grant. her current research interest lies in the fabrication and stability studies of functional food colorants from natural resources.

Ms. Indrawati is an author of Indonesian peer-reviewed papers as well as several international publications. She has been awarded for a double degree scholarship by Indonesian Government to pursuit her graduate study for two years and a half. She received the award as one of the best presenters in Natural Pigments Conference for South-East Asia in three consecutive years.

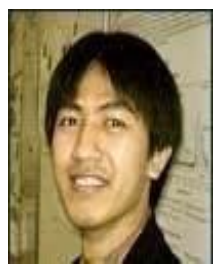

Heriyanto received his B.Sc in chemistry from Satya Wacana Christian University, Indonesia, in 2004. In 2008 and 2009, He obtained M.Sc. as a double degree program in Biology from Satya Wacana Christian University, Indonesia and in Chemistry from Kwansei Gakuin University, Japan. Currently, he is a Ph.D student in the Faculty of Biochemistry, Biophysics and Biotechnology, Jagiellonian University, Poland.
He worked as a research assistant from 2004 to 2009 and then continueshis work as a researcher at Ma Chung Research Center for Photosynthetic Pigments (MRCPP), Universitas Ma Chung, Indonesia. Since 2015, he has been invited as a lecturer in the Department of Chemistry, Universitas Ma Chung, Indonesia. He has an experience in the analysis of natural pigments for almost 14 years. His research interests include pigment analysis, analytical chemistry, spectroscopy and chromatography, as well as biochemistry of photosynthetic pigments.

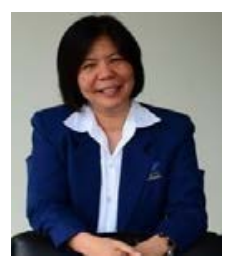

Leenawaty Limantara finished her graduate study in Kwansei Gakuin University, Japan, majored in the physical chemistry related to photosyntetic pigments in light harvesting antenna. She has been involved in several post-doctoral research in Japan, United States, United Kingdom, and Germany.

She is an invited lecturer and principal investigator in Ma Chung Research Center for Photosynthetic Pigments, Universitas Ma Chung. She has been engaged in many studies related to chlorophyll since 1991 and received many research grant from both national and international institution. Currently, she is the rector of Universitas Pembangunan Jaya, Jakarta, Indonesia

Dr. Limantara has published her work in many international journals, chapter of book, review, and national peer reviewed journal. She is the founder as well as chairwoman of the Association of Pigment Researchers in Indonesia. She is also the first Indonesian ambassador scientist for the Alexander von Humboldt Foundation, Germany. 
Polymer Chemistry 
